\title{
Teacher's Teaching Practices in the Class of Mualaf (New Convert)
}

\author{
Asmawati Suhid ${ }^{1}$, Fathiyah Mohd Fakhruddin ${ }^{1}$, Noreha Che Abah $^{1}$, Zetty Nurzuliana Rashed ${ }^{2}$, Abd. Muhsin \\ Ahmad $^{3}$, Zeinab Zaremohzzabieh ${ }^{1}$ \\ ${ }^{1}$ Faculty of Educational Studies, Universiti Putra Malaysia, Serdang, Selangor, Malaysia \\ ${ }^{2}$ Kolej Universiti Islam Antarabangsa Selangor, Kajang, Selangor, Malaysia \\ ${ }^{3}$ Faculty of Law, University of Malaya, Kuala Lumpur, Malaysia \\ Correspondence: Asmawati Suhid, Faculty of Educational Studies, Universiti Putra Malaysia, 43400 UPM \\ Serdang, Selangor, Malaysia. Tel: 603-9769-8210. E-mail: asmawati@upm.edu.my
}

Received: September 3, 2021 Accepted: September 28, 2021 Online Published: October 15, 2021

doi:10.5539/ass.v17n11p83 URL: https://doi.org/10.5539/ass.v17n11p83

\begin{abstract}
Education is highly emphasized in Islam because it can guide people to live righteous life according to Islamic law. The same also applies to mualaf or converts, who should be provided with proper education and guidance to perform their duties as true Muslims. In Malaysia, an increasing number of individuals are embracing Islam as their way of life. They are given an education and need to attend classes to ensure that they understand and practice the teachings of Islam properly. Therefore, teachers play an important role in achieving this goal by applying interesting and effective teaching methods. This study was conducted to identify the perceptions of mualaf students on their teachers' teaching practices in the classroom to ensure that they understand and practice what they have learned in class, besides strengthening their faith and morals. A total of 124 mualaf students from two educational institutions in one of the states in Malaysia were involved in this study using quantitative methods. Questionnaires were used to collect data based on the objectives of the study. The results showed that students had a positive perception of the teaching methods used by their teachers. This study also discussed some of the problems faced by mualaf students in their learning process. Overall, the findings of the study indicated that most students have a positive view of their teachers' teaching. The current findings are expected to provide input to relevant agencies and a guide to improving the quality of teaching for mualafs.
\end{abstract}

Keywords: teaching practices, Islamic Education, mualaf, faith, moral values

\section{Introduction}

Islam is an ad-Din or religion revealed to all beings. The Prophet, peace be upon him (PBUH), was sent by Allah SWT as a blessing for mankind. As stated in the Qur'an, "Verily I have not sent you, O Muhammad, except as a mercy for all the worlds", which means Islam is a religion revealed by Allah as guidance and goal of human life that ultimately leads to oneness with Allah SWT. This concept transcends race or ethnicity; any man can accept and practice Islam as a way of life. Mualaf or new relatives is a group that is given attention by Islam. For instance, the mualafs are one of the groups entitled to receive zakat. As mentioned by Allah SWT in surah al-Taubah (60:9), "Indeed, [prescribed] charitable offerings are only [to be given] to the poor and the indigent, and to those who work on [administering] it, and to those whose hearts are to be reconciled, and to [free] those in bondage, and to the debt-ridden, and for the cause of God, and to the wayfarer. [This is] an obligation from God. And God is all-knowing, all-wise." Mualafs consist of three groups: 1) teenagers, 2) adults, and 3) the elderly. Each group has the same rights in Islam as other Muslims (Mohamed \& Muhamat, 2020). In the Malaysian context, mualafs are often referred to as new brothers or Muslim brothers (Che Mat et al., 2019). In most states in Malaysia, the term mualaf or convert refers to a person who has just converted to Islam and provided with zakat to strengthen their faith and life.

Education is a basic need for the development of human civilization. Human capital development is closely related to Islamic Education. The term 'Islamic Education' refers to a comprehensive, integrated and continuous effort to help individuals master skills, build, and appreciate knowledge based on the Quran and Sunnah to perform their responsibilities as servants of Allah and caliphs on earth (Nik Pa, 2014). The word education itself was derived from the Arabic word ربى which means fertile, growing, and increasing. Therefore, tarbiyyah or education is human behavior in caring for, preserving, and educating a person until he becomes better than 
before (Suhid et al., 2014). Furthermore, education should focus on individual development in a holistic and balanced manner. Suhid et al. (2019) stated that "education should not only focus on national development and unity, and the production of human resources, but also individual development as a holistic and balanced person, in terms of his physical, emotional, spiritual, intellectual and social capabilities."

To instill understanding among mualafs, education is an effective medium in obtaining knowledge about their newly-embraced religion. Systematic and structured education not only attracts mualafs to understand Islam's teachings but also builds their confidence in the truth of the religion (Ab Rahmani et al., 2020). Thus, mualafs are not exempted from seeking Islamic knowledge to strengthen their religious beliefs. In addition, Kasim et al. (2017) stated that to ensure that a mualaf can understand Islam well, they require a basic understanding of the concept of faith because issues related to the conversion to Islam are closely related to the aspects of faith. Therefore, using appropriate teaching methods and techniques can positively impact the understanding of faith by mualafs.

Non-governmental organizations (NGOs) have been established to manage the affairs of mualafs, especially in their education, such as the Malaysian Muslim Welfare Association (PERKIM), Malaysian Chinese Muslim Association (MACMA), and Malaysian Indian Muslim Congress (KIMMA) (Abu Bakar \& Ismail, 2018). Moreover, mualafs are required to attend classes organized by the State Islamic Religious Council (MAIN) or the State Islamic Religious Department (JAIN). These classes expose them to several modules (basic, intermediate, and advanced levels) provided by the respective states. It was this issue that the educators needed to use effective teaching methods and provide adequate supervision to guarantee that the mualafs had a smooth teaching and learning process that they could apply in their everyday lives. They also have to know and understand what are the methods needed before coming into the classroom. Therefore, it is necessary to create a structured study module for mualafs, focusing on teaching and learning methods for their complete understanding of Islam. Furthermore, the modules can be used as a guideline in classes in each state to increase the beliefs of tawhid and faith among mualafs. Thus, this study surveyed the perceptions of mualaf students towards teachers' teaching practices and identified their delivery methods in classrooms. Subsequently, solutions to problems or issues that arise were proposed and discussed.

\section{Literature Review}

\subsection{Mualafs' Education System in Malaysia}

Muslims, especially mualafs who are still new in understanding Islam, need to seek knowledge, especially those related to Islam. However, because this group is new to the teachings of Islam, they need special attention and constant guidance to ensure that they are on the straight path. Furthermore, this effort should not be taken lightly because it is feared that their faith would deviate and return to their original religion due to the lack of guidance in knowledge procurement, especially in Islamic education. According to Suhid et al. (2019), mualafs should always be guided and monitored in terms of their understanding, appreciation, and practices to prevent conflict with Islamic law, and Allah SWT accepts all their practices. Therefore, mualafs must understand Islam through guidance and education by the responsible bodies to produce knowledgeable individuals with a balanced appreciation of human personality in all aspects of their lives (Norddin, 2017). In this regard, governmental bodies and NGOs have been established to manage and organize the education of mualafs. In Malaysia, individuals who have just converted to Islam are called new relatives, mualaf, or converts. It was mentioned in the Qur'an in surah al-Taubah verse 60, the term mualaf or "mualafatu qulubuhum" refers to an individual whose heart has been tamed to incline to Islam; thus, indicating that new relatives are also given attention in Islam (Che Abah et al., 2019).

In Malaysia, government bodies such as the MAIN and the JAIN are responsible for giving special attention and guidance to the mualafs in shaping their personality to lead the Islamic lifestyle and develop their Islamic knowledge (Abu Bakar \& Ismail, 2018). In addition, mualafs are educated through various programs organized by the preaching bodies to build their understanding of Islam (Che Abah et al., 2019). Apart from that, these programs, courses, and classes aim to guide them and provide understanding, appreciation, and practice of the Islamic knowledge gained in their lives as Muslims.

\subsection{Teacher's Teaching Practices and Methods}

Classes conducted for mualafs is an important initiative to ensure that they can improve their Islamic knowledge, skills, and practices. These classes are held regularly and cover several essential aspects of Islam that act as a form of support for mualafs apart from financial assistance. However, appropriate and effective teaching methods are essential to ensure their understanding and provide continuous guidance for mualafs (Mohamad et al., 2017). Hakimi Shahimi and Kasim (2019) stated that there are no systematic guidelines for teachers who 
teach modules for new relatives until now. Additionally, Yusri and Tan (2015) reported that some teachers do not master the appropriate and effective teaching methods for mualafs.

Teaching methods, in general, refer to the systematic action of teachers to achieve teaching objectives following the title of the lesson and the level of student's achievement (Johari et al., 2016). Appropriate and accurate teaching methods lead to effective learning and can affect students' understanding, changes in their practices and attitudes (Kiamsin \& Talia, 2018). Therefore, teaching requires significant elements such as purpose and target, which lead to the results and changes that are expected in students (Md Nawi, 2011).

In Islam, mualafs are considered pure children who are free from sins. Therefore, they need to be molded and educated in the best way to perform good deeds as true Muslims. Therefore, the need for appropriate and wise teaching methods should not be underestimated (Abdullah et al., 2019). Moreover, the concept of wisdom is touched by Allah SWT clearly in Surah Al-Nahl (6:125) as the following:

"Invite to the way of your Lord with wisdom and good instruction, and argue with them in a best way. Indeed, your Lord is most knowing of who has strayed from His way, and He is most knowing of who is [rightly] guided."

The "wisdom" mentioned in the Quran is in line with the findings by Mohamad et al. (2017), who reported that the method used in PERKIM Islamic Dakwah Institute in Kelantan includes the method of wisdom, apart from the various presentation and problem-solving techniques. This method of wisdom or prudentness in combination with other techniques improved the level of understanding and practices of the mualafs. Furthermore, a study conducted on 60 mualafs in one of the dakwah institutions in Melaka showed that the delivery or teaching methods of the teaching staff were at a moderate level (mean = 3.79) (Mat Sah \& Ismail, 2003). The excellent and clear presentation by the teaching staff is contributed by their experience in teaching and educating converts for over a decade.

These findings indicate the importance of appropriate and effective teaching or delivery methods during the mualafs' class. Without appropriate and effective teaching methods, it will affect the level of understanding, skills to perform worship, and the level of practice and appreciation of religion in the lives of mualafs. The contents and teaching methods should also be in accordance with the level of understanding of mualafs as a person getting to know Islam. The important syllabi as an initial exposure before moving on to a broader field include the knowledge of fardhu ain, tawhid, worship, morals, sirah and Quranic studies (Abu Bakar \& Ismail, 2018; Ismail et al., 2015). In conclusion, the variety of methods used by teachers when teaching mualaf students with the help of modules as the basis of guidance have successfully enabled students to understand their lessons better.

However, this module only acts as a guideline for teachers. Some teachers even take the initiative to prepare Weekly Lesson Plans by term for their classes. On top of that, teachers put in the effort to be creative and diversify their teaching approaches according to the level of their students to attract students' attention and make their lessons more effective. This initiative is critical, especially nowadays; it requires teachers to act creatively and innovatively in imparting knowledge, including Islamic Education, to attract students and for their teaching to be effective. According to Asmawati Suhid et al. (2021), in Islamic Education, innovation comes in the form of a new pedagogic theory, a methodological approach, a teaching method, an instructional tool, or a learning process, all of which, upon implementation, brings about significant changes in teaching and learning in terms of improved student outcomes. Therefore, this study aimed to identify the perceptions of convert students on the teaching practices of their teachers in the classroom.

\section{Methodology}

\subsection{Research Design}

A case study was conducted in one of the states in Malaysia. The reason for employing a case study is that it is a detailed, in-depth analysis of a specific situation in a real-world setting. The quantitative data obtained were analyzed using Statistical Package for The Social Sciences (SPSS) version 24.0.

\subsection{Sample and Study Location}

The researchers used a basic random sampling technique. Every member of the population has an equal probability of getting chosen under this technique. The study population consisted of 124 mualaf students from two educational institutions. Both are centers of studies for mualaf in Kelantan, Malaysia. This location was chosen because it had the most significant number of Mualafs in Malaysia. Because of the sensitivity of the 
subject, the names of the centers are kept private. The majority of statisticians agree that a sample size of 100 is required to obtain any type of significant conclusion (e.g., Hair et al., 2007).

\subsection{Measures}

Descriptive statistical analysis involving the frequency, percentage, mean, and standard deviation were used to analyze the data obtained. Van Geel et al. (2016) created the student perception questionnaire that was utilized in this study and modified for Malaysian context. The research instrument was built using Cohen et al.'s (2000) suggestions in mind and was then verified by a panel of specialists. The built instrument had a dependability index and an alpha value of 0.956 .

\subsection{Ethical Considerations}

The procedures were authorized by Universiti Putra Malaysia before the study's implementation. Prior to data collection, researchers got permission from the state's Islamic Religious Council (MAIWP) for conducting this study. Students were told that they may withdraw at any moment, even if they had already begun, and that the information gathered would be kept private and anonymous. In addition, each participant's written permission was acquired, as well as parental consent. The consent form was provided to the participants one day before the questionnaires were delivered, and the consent form was collected before the questionnaires were distributed. After receiving the consent form, respondents were requested to complete the surveys.

\subsection{Pilot Testing}

Before actual data collection, researchers distributed 24 questionnaires among Mualafs in selected educational intuitions to assess the validity of the instrument as recommended by Saunders et al. (2012). Changes to the questionnaire were made based on the comments and recommendations of the respondents.

\section{Research Findings and Discussion}

\subsection{Demographics of Mualaf Students}

Out of 124 respondents, $87.1 \%$ were male, and $12.9 \%$ were female. Most participants were Thai or Siamese $(87.1 \%)$, followed by Chinese (25.0\%), Indians (1.6\%) and others (21.0\%) (Table 1).

Table 1. Demographics of mualaf Students (N=124).

\begin{tabular}{ccc}
\hline & Frequency & Percent \\
\hline Gender & & \\
Women & 16 & $12.9 \%$ \\
Man & 108 & $87.1 \%$ \\
Nation & & \\
Thai & 65 & $52.4 \%$ \\
Chinese & 31 & $25.0 \%$ \\
Indian & 2 & $1.6 \%$ \\
Others & 26 & $21.0 \%$ \\
\hline
\end{tabular}

\subsection{Perceptions of Mualaf Students towards Teacher's Teaching}

\subsubsection{Beginning of Teaching Stage}

Table 2. Perceptions of Mualaf Students on the Beginning of Teaching ( $\mathrm{N}=124)$.

\begin{tabular}{llll}
\hline No. & Item & Mean & SD \\
\hline & My teacher & & .475 \\
1 & begins the lesson with a prayer recital. & 4.66 & .669 \\
2 & asks about the students' well-being/health. & 4.22 & .637 \\
3 & starts teaching when all students are ready. & 4.40 & .745 \\
4 & starts the lesson interestingly. & 4.27 & .647 \\
5 & offer reminders of moral values before teaching. & 4.33 & .564 \\
6 & punctuality in starting lesson. & 4.38 & .699 \\
7 & relates the content of the lesson to the students' experience. & 4.18 & .760 \\
8 & asks questions that stimulate students' enthusiasm in learning. & 4.28 & \\
\hline
\end{tabular}




\subsubsection{Teaching Development Stage}

Table 3. Perceptions of Mualaf Students on Teaching Development (N=124)

\begin{tabular}{|c|c|c|c|}
\hline No. & Item & Mean & SD \\
\hline \multicolumn{4}{|c|}{ My teacher } \\
\hline 1 & always attracts the attention of students. & 4.40 & .568 \\
\hline 2 & always inserts the words of advice. & 4.46 & .516 \\
\hline 3 & gives examples related to the realities of life. & 4.38 & .519 \\
\hline 4 & praises the students who answer questions correctly. & 4.33 & .552 \\
\hline 5 & using language that students easily understand. & 4.40 & .538 \\
\hline 6 & using interesting teaching techniques. & 4.35 & .544 \\
\hline 7 & provides examples related to the realities of life while teaching. & 4.23 & .543 \\
\hline 8 & always listens to the views of students. & 4.32 & .486 \\
\hline 9 & provides students with the opportunity to offer insights. & 4.37 & .502 \\
\hline 10 & gives students the opportunity to ask questions. & 4.41 & .494 \\
\hline 11 & always encourages the students to do good. & 4.48 & .631 \\
\hline 12 & constantly reminding students not to commit crimes. & 4.44 & .545 \\
\hline 13 & emphasizes manners with family members. & 4.44 & .515 \\
\hline 14 & Reminds students to always respect the sunnah of the Prophet PBUH. & 4.60 & .493 \\
\hline 15 & tries to shape morals by telling the stories of the apostles and exemplary individuals. & 4.54 & .500 \\
\hline 16 & strives to ensure that teaching has an impact on students. & 4.41 & .570 \\
\hline 17 & takes into account the interests of the students. & 4.29 & .506 \\
\hline 18 & takes into account the abilities of the students. & 4.25 & .550 \\
\hline 19 & answers the students' questions clearly. & 4.47 & .562 \\
\hline
\end{tabular}

\subsubsection{Closing Stage}

Table 4. Perceptions of Mualaf Students on the Closing of the Lesson $(\mathrm{N}=124)$

\begin{tabular}{|c|c|c|c|}
\hline No. & Item & Mean & SD \\
\hline & My teacher & & \\
\hline 1 & repeats important contents. & 4.38 & .550 \\
\hline 2 & asks if students do not understand. & 4.43 & .573 \\
\hline 3 & conclude the lesson by reciting Surah al-Asr. & 4.57 & .665 \\
\hline 4 & ends the lesson by reciting a prayer. & 4.62 & .535 \\
\hline 5 & advises the students to practice moral values in life. & 4.52 & .548 \\
\hline 6 & reminds the students to perform prayer. & 4.61 & .537 \\
\hline 7 & always motivates the students to continue to practice the teachings of Islam. & 4.60 & .507 \\
\hline 8 & says thank you. & 4.54 & .590 \\
\hline
\end{tabular}

Based on Tables 2, 3, and 4, it was found that the average student had a positive view of their teachers' teaching practices. The mean obtained was between $4.18-4.61$. What attracted the researcher's attention during the beginning of the teaching session was that the teacher always started the class with a prayer reading (mean $=$ $4.66, S D=.475$ ) and reminders about moral values (mean $=4.33, S D=.647$ ) before starting the lesson to strengthen the spiritual aspect of students to constantly practice the commandments of Allah SWT and stay away from His prohibitions.

Similarly, at the teaching development stage, students agreed that the teacher reminded them always to respect the Sunnah of the Prophet PBUH (mean $=4.60, S D=.493$ ) and encourage them to do well (mean $=4.48, S D$ $=.631$ ) and offered meaningful advice (mean $=4.46, S D=.516$ ). This practice is praiseworthy and should be emulated by other teachers because the mualafs should always be guided and reminded of good deeds pleasing to Allah SWT. According to Suhid et al. (2019), mualafs require constant guidance and monitoring in their understanding, appreciation, and practices to avoid conflict with Islamic law. Meanwhile, at the closing stage of the lesson, teachers constantly reminded students to perform prayers (mean $=4.61, S D=.537$ ) and motivate them to continue practicing Islamic teachings (mean $=4.60, S D=.507$ ). Finally, before ending the class, the 
teacher recited prayers with the students (mean $=4.62, \mathrm{SD}=.535)$ and instructed them to practice moral values in life (mean $=4.52, S D=.548$ ). Abdullah et al. (2019) reported that educational programs specifically for mualafs are a crucial social support platform to enhance their level of understanding of Islam and thus practice the Islamic way of life.

From the teaching aspect, students were found to have a positive view of their teachers' teaching practices. For example, teachers begin the lesson only when all students are ready (mean $=4.40, S D=.637$ ) and were punctual in starting the class (mean $=4.38, S D=.564)$. At the teaching development stage, most students agreed that their teachers gave students the opportunity to ask questions (mean $=4.41, S D=.494$ ), used a language that was easily understood by students (mean $=4.40, S D=.538$ ), gave students the opportunity to voice out their views (mean $=4.37, S D=.502$ ) and used interesting teaching techniques (mean $=4.35, S D=.544)$. In addition, to ensure that students were clear and understood the content, the teachers ask students if they have questions about the lesson (mean $=4.43, S D=.573)$ and repeat the important content (mean $=4.38, S D=.550)$. Overall, the teachers successfully employed appropriate teaching methods that attracted interest and improved students' understanding.

Generally, mualaf students consist of various races and ages from different social and cultural backgrounds; thus, continuous guidance is necessary to help them build a new self-perception after conversion and transition (Yusri $\&$ Tan, 2015). Furthermore, these new relatives need all the help and support they can get to adapt to the new environment and lifestyle within the society. Most importantly, as Muslims, differences in race, culture, and ethnicity should not be a reason to discriminate against converts in the Muslim community (Suhid et al., 2019).

\section{Conclusion}

Teachers that teach mualafs were devoted to educating and mentoring their students, according to the findings of this study. They worked hard to develop their teaching abilities in order to attract students and keep their ideas and practises alive, as well as to strengthen student-teacher relationships. On top of that, the teachers diversified their teaching methods to improve students' understanding during their lessons. Furthermore, a structured teaching method is an added value in facilitating the learning process of the mualafs who constantly strive to obtain precise information and guidance to understand Islam. Apart from that, a particular religious guidance and improvement curriculum for asnaf mualafs might help them maintain and deepen their religion. Aside from fardhu ain, the mualafs education curriculum should also focus on socio-economic support to help mualafs cope with their emotional and financial responsibilities and prepare them for any problems that may arise after their martyrdom.

\section{Limitations and Direction for Future Studies}

The outcomes of this study were the study's primary weakness. Initially, Mualafs were used as respondents in questionnaire research. As a result, the sample can only be applied to students who fall within these categories. The statistical analysis, on the other hand, simply offered numerical relationships. The researcher's subjective assessment determines how these statistics are understood. However, the findings are consistent with those of other research, boosting confidence in the conclusions. For a deeper understanding of the phenomena, more study utilizing in-depth methodologies is needed.

\section{References}

Ab Rahmani, A., Rahmat, N. A. S., Shakor, M. F. A., Nordin, N. S., \& Zakaria, M. A. (2020). Literature Review of Mualaf Study Modules in Malaysia. E-Proceedings. Syariah and Law Discourse, 1(1), 46-53.

Abd Khafidz, H. B., Bin Ain, Z., \& Rahim, N. N. (2019). Massive Open Online Course (MOOC) Online Learning Framework Massive Open Online Course (MOOC) Online Learning About Zakat. In S. A. Bhari, M. Khalid, \& M. A. Zaki Yaakob (Eds.), Empowering the Potential of Contemporary Era Converts. Institut Kajian Zakat (IKAZ), Akademi Pengajian Islam Kontemporari, Universiti Teknologi MARA.

Abdullah, N. A., Abd. Majid, M., Mohamad, N., \& Md. Hamdani, S. (2019). Perception of Mualaf Towards Fardhu Ain Mualaf Class Teaching Module (KFAM) Hulu Langat District, Selangor (Dalam Memperkasakan Potensi Mualaf Era Kontemporari). Institut Kajian Zakat (IKAZ), Akademi Pengajian Islam Kontemporari, Universiti Teknologi MARA.

Abu Bakar, S. A., \& Ismail, S. Z. (2018). Management of converts in Malaysia: Dynamic cooperation between government and non -government agencies. Jurnal Usuluddin, 46(2), 97-122. https://doi.org/10.22452/usuluddin.vol46no2.4

Che Abah, N., Suhid, A., \& Mohd Fakhrudin, F. (2019). Issues and challenges of new relatives in Malaysia: A 
Preliminary Survey. Jurnal AL-ANWAR, 8(2), 1-13.

Che Mat, A., Awang, A., Abdul Ghani, R., \& Musa, R. (2019). Some Translation Terms of "New Brother": An Analysis of Meaning Components. In Empowering the Potential of Contemporary Era Converts. Institut Kajian Zakat (IKAZ), Akademi Pengajian Islam Kontemporari, Universiti Teknologi MARA.

Cohen, S., Underwood, L. G., \& Gottlieb, B. H. (2000). Social relationships and health. In S. Cohen, L. G. Underwood, \& B. H. Gottlieb (Eds.), Social support measurement and intervention: A guide for health and social scientists. Oxford University Press. https://doi.org/10.1093/med:psych/9780195126709.001.0001

Hair, J. F., Money, A. H., Samouel, P., \& Page, M. (2007). Research methods for business. Education + Training, 49(4), 336-337. https://doi.org/10.1108/et.2007.49.4.336.2

Hakimi Shahimi, M. F., \& Kasim, A. Y. (2019). Teaching the Islamic faith to new converts at the PERKIM Islamic Dakwah Institute (IDIP): A case study. Tinta Artikulasi Membina Ummah, 5(2), 34-41.

Ismail, Z., Pozi, N., \& Ahmad, W. I. W. (2015). The level of religious knowledge of the new brother in the Islamic guidance center of the new brother Sultan Abdul Halim Mu'adzam Shah, Kedah Darul Aman. In Management issues of the Muslim brotherhood (pp. 91-93). Penerbit Universiti Kebangsaan Malaysia.

Johari, N. S., Mohd Fakhruddin, F., \& Suhid, A. (2016). Approaches and methods of teaching the prayers of Islamic Education teachers according to the perspective of students. Online Journal of Islamic Education, 4(2), 46-53.

Kasim, A. Y., Hamid, S. A., \& Jemali, M. (2017). Teaching of Faith among Converts at the PERKIM Islamic Dakwah Institute. Perspektif: Jurnal Sains Sosial Dan Kemanusiaan, 9(3), 89-100.

Kiamsin, L., \& Talia, R. (2018). History teaching methods that students are interested in and its justification. Malaysian Journal of Social Sciences and Humanities, 3(2), 137-145.

Mat Sah, M. A., \& Ismail, M. (2003). Status of learning programs among new relatives: A case study in the state of Melaka. Pertanika Journal Social Science and Humanities, 11(1), 81-95.

Md Nawi, N. H. (2011). Teaching and learning: A re-examination of basic concepts according to the perspective of the idea of Islamization of modern science. Kertas kerja yang dibentangkan di Kongres Pengajaran \& Pembelajaran UKM pada, Pinang, Malaysia.

Mohamad, M., Abd. Majid, M., \& Omar, A. N. (2017). Methodology of teaching converts at PERKIM Islamic Dakwah Institute (IDIP). E-Jurnal Penyelidikan Dan Inovasi, 4(2), 215-223.

Mohamad, N., Abdul Majid, M., \& Mohd Nasir, B. (2017). The application of the element of al-tadarruj in the teaching module of the new brother. Jurnal Sultan Alauddin Sulaiman Shah, Special Issue, 94-107.

Mohamed, S. N., \& Muhamat, R. (2020). A Brief Analysis of the Impact of Dakwah to the Mualaf in Hulu Langat, Selangor. BITARA International Journal of Civilizational Studies and Human Sciences, 3(2), 110-123.

Nik Pa, N. A. (2014). Understanding the concept of discipline in primary and secondary school Islamic education in Malaysia: The Challenges of Transformation. In Islamic Education in Malaysia: Challenges and Solutions. Akademi Pengajian Islam, Universiti Malaya.

Norddin, M. F. (2017). The practice of appreciating Islamic education for Muslim students in Chinese National Type Schools (PhD Thesis). Universiti Teknologi Malaysia.

Saunders, M., Lewis, P., \& Thornhill, A. (2007). Research methods (4th ed.). Pearson Education.

Suhid, A., Ahmad, Abd. M., Mohd Fakhruddin, F., \& Che Abah, N. (2019). The application of 'Urf in the customary practices and culture of new relatives in Malaysia: A Preliminary Survey. International Journal of Humanities, Philosophy, Language, 2(5), 65-77.

Suhid, A., Fakhruddin, F. M., Roslan, S., Mutalib, L. A., \& Noh, M. A. C. (2014). Private Islamic primary school teachers' commitment in human capital development in Malaysia. Mediterranean Journal of Social Sciences, 5(27 P2), 766-766. https://doi.org/10.5901/mjss.2014.v5n27p766

Suhid, A., Mohd Fakhruddin, F., Abdul Mutalib, L., \& Ahmad, Abd. M. (2019). Juvenile Delinquent Pupils' Perceptions on the Teaching of Islamic Education: A Preliminary Study. International Journal of Academic Research in Progressive Education and Development, 8(4), 340-354. https://doi.org/10.6007/IJARPED/v8-i4/6534

Suhid, A., Naser, M. Y. M., Ahmad, A. M., Abah, N. C., Jusoh, R., \& Zaremohzzabieh, Z. (2021). Challenges 
and Readiness of Islamic Education Teachers in Innovative Teaching and Learning. Jurnal Ilmiah Peuradeun, 9(2), 293-308. https://doi.org/10.26811/peuradeun.v9i2.588

Keuning, T., van Geel, M., Visscher, A., Fox, J.-P., \& Moolenaar, N. (2016). The transformation of schools' social networks during a data-based decision making reform. Teachers College Record, 118(9), 1-33.

Yusri, S. F. Z., \& Tan, A. M. (2015). Teaching Islamic Education to converts: A review of the literature. Prosiding Seminar Pengurusan Islam. Ke Arah Pemantapan Ummah, 2015.

\section{Copyrights}

Copyright for this article is retained by the author(s), with first publication rights granted to the journal.

This is an open-access article distributed under the terms and conditions of the Creative Commons Attribution license (http://creativecommons.org/licenses/by/4.0/). 